$\begin{array}{ll}\text { Volume } & : 06 \\ \text { Nomor } & : 02 \\ \text { Bulan } & : \text { Mei } \\ \text { Tahun } & : 2020 \\ \text { http } & : / / \text { ejurnal.pps.ung.ac.id/index.php/AKSARA/index }\end{array}$

\title{
Tinjauan Hukum Islam Terhadap Adat Peminangan Melalaken Di Desa Tanah Bara Aceh
}

\author{
Khairuddin \\ STAI Syekh Abdur Rauf Aceh Singkil \\ khairuddinazka15@gmail.com
}

Received: 23 Februari 2020; Revised: 27 April 2020; Accepted: 28 April 2020

DOI: http://dx.doi.org/10.37905/aksara.6.2.103-110.2020

\begin{abstract}
ABSTRAK
Di kawasan Desa Tanah Bara Kec. Gunung Meriah Aceh Singkil Provinsi Aceh masih banyak ditemukan untuk menempuh pernikahan dengan cara melalaken, Oleh karena itu, penelitian ini bertujuan untuk mengetahui bagaimana praktik adat peminangan melalaken, penyebab terjadinya peminangan melalaken di Kecamatan Gunung Meriah dan pandangan Islam terhadap hukum praktik peminangan melalaken. Adapun metode penelitian yang digunakan ialah pendekatan kualitatif. Adapun teknik yang digunakan dalam pengumpulan data melalui wawancara mendalam dengan informan. Hasil penelitian, melalaken dilakukan oleh seseorang laki laki yang hendak menikah dengan wanita, dengan membawanya pergi dari rumah dengan maksud untuk meminang dan kemudian diserahkan kepada kepala desa atau pengurus syara' setempat atau desa yang lain. 25 persen masyarakat DesaTanah Bara Kecamatan Gunung Meriah mempraktikkan melalaken untuk melakukan peminangan. Peminangan adat melalaken dalam perspektif hukum Islam dibolehkan, jika ditemani oleh seorang perempuan ketika melakukan melalaken. Namun akan menjadi haram, jika dilakukan oleh laki-laki yang membawa wanita kerumah kepala desa atau tempat yang lain tanpa ditemani oleh mahram atau perempuan yang menemaninya.
\end{abstract}

\section{PENDAHULUAN}

Islam merupakan agama yang sesuai dengan fitrah manusia, Salah satunya keinginan manusia untuk memperoleh keturunan dan itu hanya dapat ditempuh melalui hubungan seksual antara seorang laki-laki dan seorang wanita. Hubungan yang dimaksud haruslah merupakan hubungan yangdilakukan sesuai dengan hukum Allah sebagaimana terdapat dalam AlQur"an,bahwa hubungan seksual haruslah didasarkan pada ikatan yang sah yaitu pernikahan (Anshori, 2011). Perkawinan dalam pandangan Islam bukanlah hanya urusan perdata saja, bukan pula sekedar urusan keluarga dan masalah budaya tetapi masalah dan peristiwa agama. Oleh karena perkawinan itu dilakukan untuk memenuhi perintah Allah dan sunnah Nabi Muhammad Saw ( Syarifuddin, 2003)

Sebelum melaksanakan pernikahan biasanya dahului peminangan. Peminangan dalam perkawinan merupakan fase ketiga dari proses menuju gerbang nikah. Fase pertama adalah fase Tafkir. Yakni tahapan berfikir untuk menetukan apakah dirinya sudah layak menikah atau belum. Seperti taraf berpikir yang dimaksud bukan sekedar karena adanya perubahan dan peningkatan apa yang dipikirkan, misalnya dari sekedar memikirkan diri sendiri lalu keluarga atau umat manusia. Selama peningkatan taraf berfikir tersebut tidak dibangun oleh satu pandangan hidup tertentu makaperubahan yang dihasilkan tidak akan berkekalan karena mudah berubah, tidak mampu memberikan ketenangan hidup serta tidak dapat memecahkan berbagai persoalan hidup manusia. Dengan demikian, orang tersebut tidak akan pernah bangkit. Fase yang kedua adalah fase tashmim, fase pemantapan. Pada fase ini, seseorang telah yakin bahwa 


$\begin{array}{ll}\text { Volume } & : 06 \\ \text { Nomor } & : 02 \\ \text { Bulan } & : \text { Mei } \\ \text { Tahun } & : 2020 \\ \text { http } & : \text { //ejurnal.pps.ung.ac.id/index.php/AKSARA/index }\end{array}$

dirinya telah layak untuk kawin, sebagaimana telah dianjurkan oleh agama dengan berbagai kriteria yang telah dipatok, artinya dari sebelum meminang melihat bibit bebet dan bobotnya supaya kedepanya tidak ada penyesalan. Selanjutnya fase ketiga ialah fase meminang, untuk tahapan ini, diharapkan benar-benar yakin untuk melangkah kejenjang yang lebih inti yaitu perkawinan (Djalil, 2000). Peminangan itu disyari'atkan dalam suatu perkawinan yang waktu pelaksanaanya diadakan sebelum berlangsungnya akad nikah, keadaan ini pun sudah membudaya di tengah masyarakat dan dilaksanakan sesuai dengan tradisi masyarakat setempat. Syari'at menetapkan aturan-aturan tertentu dalam peminangan ini, dalam tradisi Islam sebagaimana dalam hadis Nabi yang mengajukan pinangan itu adalah pihak laki-laki itu sendiri yang datang kepada pihak perempuan untuk menyampaikan pinangannya.

Aceh Singkil merupakan salah satu dari bagian wilayah Provinsi Aceh yang memiliki tradisi dan adat-istiadat yang masih kental dan melekat disetiap aspek kehidupan masyarakatnya. Seperti adat perkawinan, di daerah Aceh Singkil sebagai hasil proses panjang pengalaman secara turun-temurun yang dibentuk masyarakat di Aceh Singkil, maka terbentuklah aneka ragam adat perkawinan. Banyak perbedaan antara satu adat perkawinan di Aceh Singkil dengan adat yang terdapat di daerah lainnya (Radius, dkk, 2008).

Sementara praktik peminangan melalaken yang terjadi di masyarakat Aceh Singkil di Desa Tanah Bara Kecamatan Gunung Meriah ialah peminangan dengan cara seorang anak lakilaki yang hendak meminang seorang anak perempuan dengan membawa anak perempuan tersebut ke salah satu rumah tokoh agama di suatu desa atau perangkat Desa seperti, keucik gampong, imam gampong, atau bilal gampong untuk melangsungkan akad perkawinan, dengan waktu yang tidak ditentukan sampai terjadi suatu perundingan dan kesepakatan diantara kedua belah pihak keluarga yang terlibat melalaken tentang pelaksanaan dan proses pernikahan.

\section{TINJAUAN PUSTAKA}

\section{Pengertian Peminangan}

Peminangan ialah mengakar pada kata pinang-meminang yang artinya melamar, meminta, mempersunting, dan menanyakan (Endarmoko, 2006). Dalam bahasa arab peminangan disebut khitbahyang diartikan sebagai meminang atau melamar (Munawir, 1984) Secara Etimologi, meminang atau melamar mempunyai arti; "meminta wanita untuk dijadikan isteri (bagi diri sendiri atau orang lain)". Sedangkan menurut terminologi peminangan ialah kegiatan upaya kearah terjadinya hubungan perjodohan antara seorang pria dengan seorang wanita, meminang juga dikenal dengan istilah bertunangan yang artinya; Bersepakat akan menjadi suami isteri (Syahrani, 2009).

Menurut Jad (2008) peminangan atau disebut khitbah secara terminologi ialah "pendahuluan, pendekatan dan permintaan seorang laki-laki untuk menikah dan mengikat janji dengan seorang wanita". Pinangan tidak selesai hanya dengan permintaan laki-laki menjadi suami seorang wanita diterima, dan hatinya tenang karena wanita tersebut akan jadi isteri yang cocok untuknya. Akan tetapi kedua belah pihak perlu menyempurnakan pinangan dengan segala sesuatu yang berkaitan dengan pelaksanaan pernikahan, seperti pemberian mahar, perabot rumah tangga dan lain sebagainya. Oleh karena itu pinangan tidak dianggap sebagai akad nikah. Menurut Rasjid (2005) meminang artinya menyatakan permintaan untuk menikah dari orang laki-laki kepada seorang perempuan atau sebaliknya dengan perantaraan seorang yang dipercayai, peminangan tersebut diperbolehkan dalam agama Islam terhadap gadis atau janda yang telah habis masa iddahnya.

Menurut Badawi (2006) peminangan adalah "ajakan kawin kepada seorang perempuan dengan wasilah yang sudah dikenal oleh masyarakat luas. Jika ada kecocokan, maka terjadilah perjanjian akan menikah". Menurut Sabiq (2006) peminangan adalah "seorang laki-laki 


$\begin{array}{ll}\text { Volume } & : 06 \\ \text { Nomor } & : 02 \\ \text { Bulan } & : \text { Mei } \\ \text { Tahun } & : 2020 \\ \text { http } & : / / \text { ejurnal.pps.ung.ac.id/index.php/AKSARA/index }\end{array}$

meminta kepada seorang perempuan untuk menjadi isterinya, dengan cara-cara yang sudah umum berlaku di tengah-tengah masyarakat". Sedangkan menurut al-Zuhaily (1997) peminangan ialah menyatakan keinginan menikahi wanita yang ditentukan, dan memberitahukan kepada wali perempuan tentang maksudnya. Dan menyampaikan kehendaknya secara langsung atau dengan melalui perantara keluarganya.

Menurut Amir Syaripuddin (2003) peminangan ialah sebagai penyampaian kehendak untuk melangsungkan ikatan perkawinan. Peminangan disyariatkan dalam suatu perkawinan yang dilaksanakan sebelum akad pernikahan. Menurut Shihab (2009) khitbah atau peminangan merupakan salah satu persiapan menuju jenjang yang serius yakni pernikahan yang disyari'atkan Allah swt yang dilaksanakan sebelum terlaksananya akad pernikahan. Hal ini bertujuan untuk lebih mengenal masing-masing calon suami dan calon istri baik prilaku, maupun kecendrungan satu sama laiannya dengan harapan dapat memasuki perkawinan dengan persaan yang mantap (Hawwas, 2009).

Berdasarkan beberapa pengertian di atas dapat dipahami, bahwa peminangan merupakan suatu proses awal seorang laki-laki yang ingin menikah meminta dan menyampaikan keinginannya atau wakilnya kepada seorang wanita yang bukan mahramnya untuk dijadikan isteri.

\section{Hukum Peminangan}

Dalil terkait hukum peminangan. Dalam Alquran dan hadis telah menggatur khitbah serta hal-hal yang berkaitan dengan hal peminangan, namun demikian tidak ditemukan dengan secara jelas dan tertuju adanya perintah atau larangan didalam melakukan peminangan. Khitbah bukanlah syarat sah dari nikah, andaikan tidak melangsungkan khitbah, pernikahan tersebut tetaplah sah dalam hukumnya, akan tetapi melaksanankan khitbah adalah kebiasaan dan sarana untuk melaksanakan sebuah pernikahan. 235 yaitu:

Adapun ayat yang berkaitan dengan meminang terdapat dalam surah al-Baqarah ayat

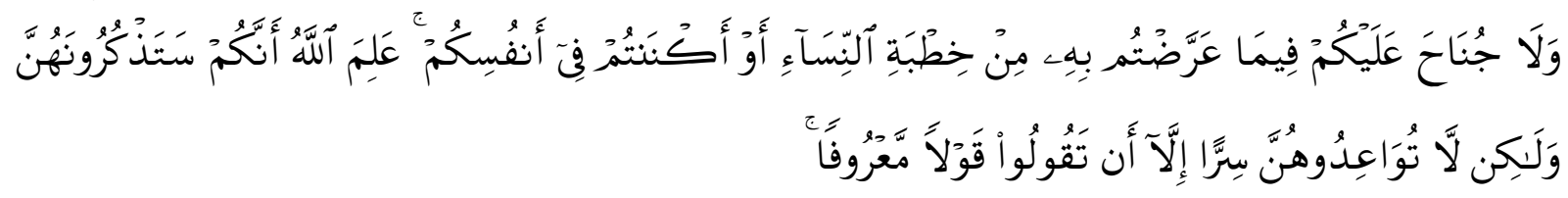

Artinya: Dan tidak ada dosa bagi kamu meminang wanita-wanita itu dengan sindiran atau kamu Menyembunyikan (keinginan mengawini mereka) dalam hatimu. Allah mengetahui bahwa kamu akan menyebut-nyebut mereka, dalam pada itu janganlah kamu Mengadakan janji kawin dengan mereka secara rahasia, kecuali sekedar mengucapkan (kepada mereka) Perkataan yang ma'ruf. (QS. Al-Baqarah: 235).

Dasar hadisnya yaitu:

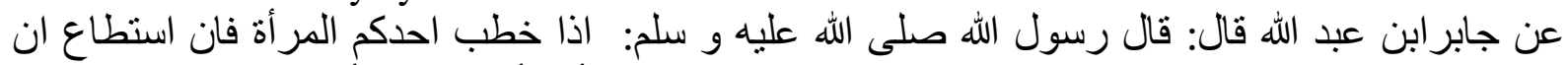

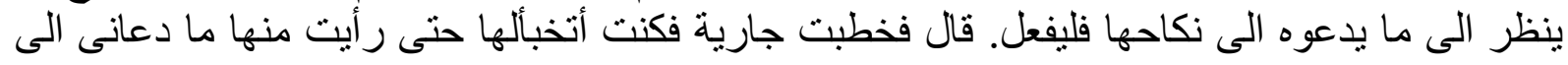

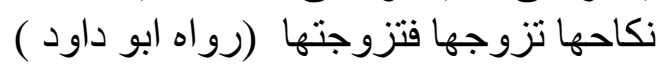

Artinya: "dari Jabir bin Abdullah berkata: berkata Rasulullah Saw "Jika salah seorang kamu meminang seorang perempuan sekiranya ia dapat melihat sesuatu darinya yang mampu menambah keinginan untuk menikahinya maka hendaklah ia meilihatnya”. Jabir berkata lagi "maka aku meminang seorang wanita, kemudian aku bersembunyi disebuah tempat, sehingga aku dapat melihatnya, sehingga membuatku ingin menikahinya, maka setelah itu aku menikahinya (HR Abu Daud) (Al-Albani 2007). 


$\begin{array}{ll}\text { Volume } & : 06 \\ \text { Nomor } & : 02 \\ \text { Bulan } & : \text { Mei } \\ \text { Tahun } & : 2020 \\ \text { http } & : / / \text { ejurnal.pps.ung.ac.id/index.php/AKSARA/index }\end{array}$

Para ulama berbeda pendapat dalam menarik kesimpulan tentang hukum meminang, pendapat dari madzhab syafie $i$ bahwa hukumnya adalah mustahhab (dianjurkan) karena Rasulullah juga pernah melakukanya, yaitu saat beliau meminang Aisyah Binti Abi Bakr dan Hafishah binti Umar r.a (Mashry 2010). Menurut jumhur ulama fikih hukum meminang adalah sunnah, begitu juga menurut Imam Al-Ghazali mengemukakan pendapat bahwa melakukan khitbah hukumnya sunnah, karena khitbah merupakan perbuatan Rasul dan diikuti oleh pengikutnya (Rusyd, 1999)

Dari beberapa dalil baik al-Qur"an maupun sunnah telah menjelaskan hukum khitbah begitu juga dengan pehaman para ulama terkait meminang tersebut yakni hukumnya sunnah demi mewujudkan pernikahan yang sakinah, mawaddah dan warahmah

\section{Hikmah Peminangan}

Peminangan memiliki hikmah yang dapat diserap di antaranya: perkenalan antara calon suami dan calon istri, sehingga mereka akan tahu watak dan prilaku masing-masing. Walaupun demikian harus sesuai ketentuan agama Islam. Hal demikian diperbuat agar kedua belah pihak dapat saling menerima dengan ketentraman, ketenangan, keserasian dan cinta sehingga timbul sikap saling menjaga, merawat dan melindungi. Ketergesaan dalam akad pernikahan akan dikhawatirkan pernikahan yang tidah bertahan lama (Hawwas, 2009)

\section{METODE PENILITIAN}

Adapun metode penelitian yang digunakan adalah pendekatan kualitatif. Menurut Moleong (2010) penelitian kualitatif adalah penelititan yang bermaksud untuk memahami fenomena tentang apa yang dialami oleh subjek penelitian misalnya prilaku, persepsi, motivasi, tindakan. Penelitian kualitatif mempunyai dua tujuan utama, yang pertama yaitu, menggambarkan dan mengungkapkan, kedua menggambarkan dan menjelaskan.

\section{Jenis Penelitian}

Jenis Jenis penelitian yang digunakan yaitu Library Research dan Field Research. Library Research (Penelitian Kepustakaan), yaitu dengan menelaah serta membaca buku-buku, kitab-kitab, jurnal, karya ilmiah yang berkaitan dengan topik pembahasan serta bahan pendukung lainnya yang mempunyai hubungan dengan masalah yang akan dibahas kemudian dikategorikan sesuai dengan data yang diperlukan untuk menuntaskan karya ilmiah ini sehingga mendapatkan hasil yang valid. Field Research (penelitian lapangan). Pada metode ini dilakukan dengan cara meneliti dan mengobservasi lapangan terhadap analisis tentang Praktik peminangan adat Melalaken di Desa Tanah Bara Kecamatan Gunung Meriah Kabupten Aceh Singkil. Selain itu, peneliti juga mengadakan observasi dan wawancara yang mendalam untuk mendapatkan data yang lebih konkrit. Hasil observasi dan wawancara tersebut penulis olah dengan cara mengembangkan data yang ada di lapangan dan menggabungkannya dengan data yang pernah didapatkan sebelumnya. Selain itu penulis juga mengkaji beberapa literatur buku, artikel, koran dan lainnya yang terkait dengan pembahasan ini.

\section{Teknik Pengumpulan Data}

Dalam penelitian ini teknik pengumpulan data yang dipergunakan adalah observasi. Menurut Nasution (2004) observasi ialah: suatu teknik untuk memperoleh informasi tentang kelakuan manusia seperti terjadi dalam kenyataan. Dengan observasi dapat diperoleh gambaran yang lebih jelas tentang kehidupan sosial, yang sukar diperoleh dengan metode lain. Observasi juga dilakukan jika belum banyak keterangan dimiliki tentang masalah yang diselidiki. Observasi diperlukan untuk menjajakinya dan fungsinya sebagai eksplorasi. Observasi di sini 


$\begin{array}{ll}\text { Volume } & : 06 \\ \text { Nomor } & : 02 \\ \text { Bulan } & : \text { Mei } \\ \text { Tahun } & : 2020 \\ \text { http } & : / / \text { ejurnal.pps.ung.ac.id/index.php/AKSARA/index }\end{array}$

akan dilakukan dengan cara pengamatan secara langsung menyangkut tentang praktik adat peminangan Melalaken di Desa Tanah Bara Kecamatan Gunung Meriah Kabupaten Aceh Singkil. Teknik pengumpulan data selanjutnya wawancara, menurut Bungil, (2009) wawancara adalah: suatu kegiatan yang dilakukan untuk memperoleh keterangan untuk tujuan penelitian dengan cara tanya jawab sambil bertatap muka antara pewawancara dengan informan. Wawancara yang berstruktur dilakukan dengan terlebih dahulu mempersiapkan daftar pertanyaan yang menjadi pokok pembicaraan secara fokus. Interview ini dilakukan dengan mewawancarai narasumber dari lokasi penelitian yang terdiri dari tokoh agama, tokoh adat, tokoh masyarakat dan masyarakat yang ada di Desa Tanah Bara Kecamatan Gunung Meriah Kabupaten Aceh Singkil, data yang diperoleh diperlukan sebagai sumber untuk diolah dan dianalisa.

\section{HAIL PENELITIAN DAN PEMBAHASAN}

Berbagai daerah Indonesia khususnya wilayah provinsi Aceh masing-masing daerah mempunyai tata-cara melakukan perkawinan dan peminangan atau pertunangan. Perkawinan merupakan perbuatan yang sangat dianjurkan oleh Rasulullah Saw untuk segera melaksanakannya dengan maksud dan tujuan supaya memelihara diri dari perbuatan yang dilarang Allah dan rasulnya. Melakukan peminangan juga dianjurkan oleh Rasulullah saw sebelum melangsungkan akad perkawinan. Pada umumnya orang Aceh melakukan peminangan dengan datang langsung membawa perlengkapan adat meminang atau dengan melalui perwakilan yang diutus oleh keluarga laki-laki untuk melakukan peminangan.

Berbicara tentang perkawinan, proses awal yang harus dilakukan adalah melakukan peminangan, dalam adat istiadat di kawasan Kabupaten Aceh Singkil sebelum melakukan peminangan biasanya ada disebut adat merisik. Merisik Adalah suatu upacara penjajakan dimana salah satu pihak calon pengantin laki-laki maupun perempuan ingin mengungkapkan isi hatinya untuk menjalin hubungan perkawinan. Dalam acara adat merisik biasanya dilakukan oleh keluarga laki-laki dengan mengutus seseorang yang dipercayai, berpengalaman dan sudah dikenal baik oleh keluarga si wanita untuk mendatangi keluarga si wanita (Radius, 2008).

Hal ini bertujuan agar apabila rencana perkawinan ditolak oleh pihak keluarga perempuan maka keluarga pihak laki-laki tidak mendapat aib yang akan memalukan. Kemudian setelah tahap awal sudah dijalankan dan utusan yang diutus oleh keluarga menyampaikan hasil pertemuannya kepada pihak keluarga laki-laki. Setelah proses awal ini sudah selesai dan kemudian keluarga pihak laki-laki mengetahui bagaimana respon dan tanggapan pihak keluarga wanita selanjutnya adalah melakukan peminangan atau disebut mengido (meminang).

Meminang (mengido) adalah upacara resmi yang dilaksanakan oleh pihak laki-laki. Utusan pihak laki-laki beserta pemuka adat, mendatangi rumah kediaman pihak perempuan, dengan membawa alat perlengkapan yang dibawa antara lain adalah sebuah pepinangen, yaitu cerana yang berisikan sirih pinang, cerana yang ditutupi dengan kain bersulam benang emas diserahkan kepada pihak perempuan untuk dicicipi isinya. Semua hadirin yang hadir di pihak pengantin perempuan menyicipi sirih pinang secara bergantian (Radius dkk, 2008).

Setelah itu pihak perempuan menanyakan kepada para utusan pihak laki-laki tentang maksud dan tujuan kedatangan mereka, pihak laki-laki selanjutnya menyampaikan maksud hati yang sesungguhnya, yaitu untuk meminang anak gadis di rumah tangga tersebut untuk ditunangkan atau dinikahkan dengan seorang pemuda. Pada prinsipnya kesimpulan atau persetujuan tentang diterima atau tidaknya lamaran dimaksud dapat disampaikan pada saat itu juga. Namun sesuai dengan kebisaaan ungkapan penerimaan atau persetujuan pinangan tidak secara spontan diungkapkan. Semacam ada musyawarah kecil diantara sanak famili perempuan tetap diadakan sebelum dinyatakan penerimaan pinangan. 


$\begin{array}{ll}\text { Volume } & : 06 \\ \text { Nomor } & : 02 \\ \text { Bulan } & : \text { Mei } \\ \text { Tahun } & : 2020 \\ \text { http } & : / / \text { ejurnal.pps.ung.ac.id/index.php/AKSARA/index }\end{array}$

Selain peminangan yang sudah biasa dilakukan terdapat praktek peminangan adat melalaken ini merupakan suatu peminangan adat yang ada di kabupaten Aceh Singkil seperti di Desa Tanah Bara Kecamatan Gunung Meriah. Peminangan adat melalaken ialah dilakukan oleh seseorang laki-laki yang hendak menikah dengan wanita yang menjadi pilihan hatinya dengan membawanya pergi dari rumah yang di dampingi oleh seorang perempuan atau disebut (penentuai) dengan maksud untuk meminang dan kemudian diserahkan kepada kepala desa setempat atau desa yang lain. Kemudian kepada kepala desa tersebut memberi tahukan kepada keluarga perempuan yang telah diserahkan kepadanya bahwa anak gadis tersebut enggo melalaken (sudah dibawa dan diserahkan kepada geucik dengan tujuan meminang).

Akan tetapi dalam proses peminangan ini pada prakteknya yang terjadi kebanyakan yang melakukan melalaken wanita tidak membawa mahram atau orang lain sebagai teman siperempuan dalam istilah adat Singkil disebut (penentuai). Setelah laki-laki menyerahkan gadis yang dibawanya pada kepala desa proses peminangan Melalaken selanjutnya masuk pada tahap pemberitahuan kepada pihak keluarga perempuan, pada biasanya kepala desa di mana terjadi melalaken memberitahukan kepada:

a. Anak Bayo Tan Daholi/ Silih Daholi (Abang ipar)

b. Tukhang Dabekhu ( Saudara perempuan)

Kepala desa tersebut memberitahukan bahwa anak perempuan dari keluarga sipulan sudah Melalaken dan sudah ditangani secara hukum dan adat, pada kebiasaannya proses pemberitahuan ini berlangsung selama empat hari atau lebih. Setelah proses pemberitahuan dan kelurga pihak wanita telah mengetahui selanjutnya dimulai dengan acara disebut muka utang adat dan hukum kepada pihak wanita yang dihadiri oleh tokoh adat atau disebut sintua kedua belah pihak. Proses muka utang adat dan hukum diartikan sebagai proses penentuan mahar si wanita dan penentuan tanggal perkawinan, pada penentuan utang adat inilah merupakan suatu proses yang sangat rumit dan panjang apabila mahar yang harus diberikan kepada pihak wanita terlalu tinggi dan pihak pria tidak sanggup memenuhinya.

Proses adat istiadat yang sudah menjadi suatu kebiasaan dan dipertahankan oleh masyarakat peminangan adat melalaken ini menjelaskan bahwa proses peminangan dengan cara melalaken menimbulkan perbuatan hukum. Melalaken dengan cara membawa seorang wanita pergi keluar rumah dengan laki-laki yang bukan mahramnya dan tidak ditemani oleh wanita lain atau mahramnya, merupakan perbuatan yang dilarang dalam hukum karena seorang lakilaki berdua-duaan dengan wanita yang bukan mahramnya apalagi melakukan perjalanan jauh sampai berhari-hari tanpa ditemani muhrim seperti hadis yang diriwayatkan dari ibnu Abbas.

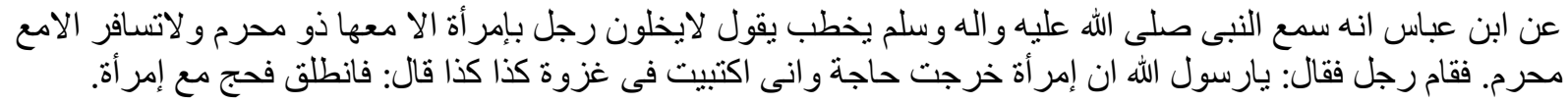

Artinya: Dari ibnu Abbas bahwa beliau mendengar Rasulullah Saw berkhutbah beliau bersabda "janganlah sekali-sekali seorang pria bersendiri dengan seorang wanita kecuali wanita itu didampingi muhrimnya, dan seorang perempuan tidak boleh melakukan perjalanan kecuali beserta muhrimnya. Seorang laki-laki berdiri lalu berkata yarasulullah isteriku keluar untuk menunaikan ibadah haji sedangkan aku telah mendaftarkan diri akan mengikuti perang anu dan anu. Rasulullah saw bersabda berangkatlah den tunaikanlah ibadah haji bersama isterimu (Syaukani 1994) 


$\begin{array}{ll}\text { Volume } & : 06 \\ \text { Nomor } & : 02 \\ \text { Bulan } & : \text { Mei } \\ \text { Tahun } & : 2020 \\ \text { http } & : \text { //ejurnal.pps.ung.ac.id/index.php/AKSARA/index }\end{array}$

Peminangan melalaken tanpa mahramnya dikhawatirkan berbuat zina. Hukum Islam sangat melarang perbuatan yang mengarah kepada perbuatan zina apalagi sampai melakukannya. seperti yang disebutkan dalam Qs Al-Israa 32.

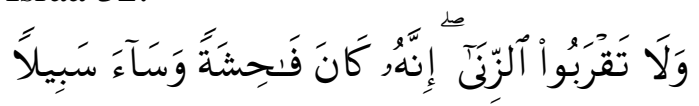

Artinya: Dan janganlah kamu mendekati zina; Sesungguhnya zina itu adalah suatu perbuatan yang keji dan suatu jalan yang buruk. (Qs. Al Israa': 32)

Namun peminangan melalaken tidak semua seperti yang disebutkan di atas, sebagian dari masyarakat Tanah Bara melalaken dengan membawa mahram sampai ke tempat pengurus desa sehingga tidak dikhawatirkan untuk melakukan perbuatan zina dan hal yang semacam ini diperboleh dalam pandangan hukum Islam.

\section{PENUTUP}

Tinjauan hukum Islam terhadap adat peminagan melalaken di Desa Tanah Bara Kecamatan Gunung Meriah yaitu:Melalaken ialah dilakukan oleh seseorang laki-laki yang hendak menikah wanita, dengan membawanya pergi dari rumah dengan maksud untuk meminang dan kemudian diserahkan kepada kepala desa atau pengurus syara' setempat atau desa yang lain. 25 persen masyarakat Desa Tanah Bara Kecamatan Gunung Meriah mempraktikkan melalaken untuk melakukan peminangan pada pernikahan. Tinjauan hukum Islam terhadap Peminangan adat melalaken dibolehkan, jika dilakukan dengan membawa mahram atau ditemani oleh seorang perempuan ketika melakukan melalaken. Namun akan menjadi haram, jika dilakukan oleh laki-laki yang membawa wanita kerumah kepala desa atau tempat yang lain tanpa ditemani oleh mahram atau perempuan yang menemaninya.

\section{DAFTAR PUSTAKA}

Anshori,Abdul Ghofur. 2011. Hukum Perkawinan Islam, Prespektif Fiqih dan Hukum Positif Yogyakarta:UIIPress.

Azzam, Abdul Aziz Muhammad dan Hawwas, Abdul Wahhab Sayyed. 2009. Fiqh Munakah: Khitbah, Nikah dan Talak, Jakarta: Sinar Grafika Offest.

Al-Albani, Muhammad Nashiruddin. 2007. Shahih Sunan Abu Daud, (terj; Tajuddin Arief, Abdul Syukur Abdul Razak dan Muhammad Rifa'i Utsman), Jakarta: Pustaka Azzam.

Al-Zuhaily, Wahbah. 1997. Al-Fiqh Al-Islam wa Adillatuh, jilid IX Beirut: Dar al Fikr.

Djalil, Abdul dkk. 2000.Fiqih Rakyat, Yogyakarta: LKIS.

Endarmoko, Eko. 2006. Kamus Tesaurus Bahasa Indonesia, Jakarta: Gramedia.

Jad, Syeikh Muhammad. 2008. Fikih Sunnah Wanita Panduan Lengkap Menjadi Wanita Shalihah, (terj; Matsuri Irham, Nurhadi), Jakarta: Pustaka Al-Kausar.

Mashry, Syeikh Mahmud Ali. 2010, Bekal Pernikahan, Jakarta : Qisthi Press.

Munawwir, Warson. 1984. Kamus Arab-Indonesia, Yokyakarta: PP al-Munawir.

Moleong, Lexy J. 2010, Metodologi Penelitian Kualitatif, Bandung: PT Remaja Rosda Karya.

Radius, dkk. 20008. Adat Perkawinan Etnis Singkil, (Banda Aceh: Pemerintah Provinsi Nanggroe Aceh Darussalam Dinas Kebudayaan Dan Pariwisata.

Rusyd, Ibnu. 1999. Bidayatu al-Mujtahid wa Nihayatu al-Muqtashid, Jilid. II, Cet. I, Semarang: As-Sifa.

Rasjid, Sulaiman. 2005. Fiqh Islam, Bandung: Sinar Baru Algesindo. 


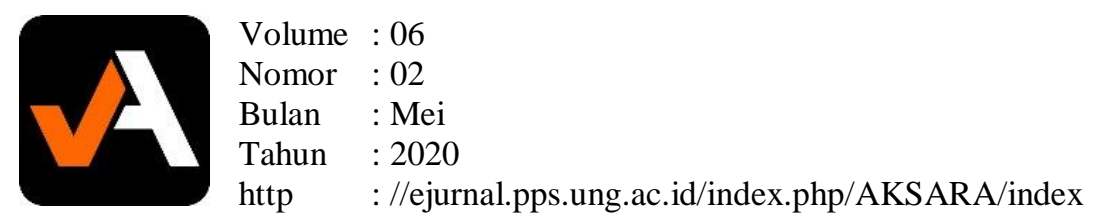

Syarifuddin, Amir. 2003. Hukum Perkawinan Islam Indonesia Antara Fiqh Munakahat dan Undang-undang Perkawinan, Jakarta: Kencana.

Sabiq, Sayyid. 2006. Fiqih Sunnah, Jakarta: Pena Pundi Aksara.

Tihami dan Sohari Syahrani. 2009.Fikih Munakahat, Kajian Fikih Nikah Lengkap Jakarta: PT. Raja Grafindo Persada. 